\title{
Positive Study on the Price-earnings Ratio for the Listed Companies in the Shanghai and Shenzhen Stock Market
}

\author{
Sheng Li and Hongzhen Liu \\ Management school, Wuhan University of Science and Technology \\ Wuhan, china 430081 \\ Lisheng@wust.edu.cn
}

Keywords: Listed company; P/E ratio; Stock market: Market value

\begin{abstract}
Based on the actual situation of China's Shanghai and Shenzhen A-share market, the situation of China's stock market price earnings ratio, and combined with the various relevant data during 2014-2016, A shares of the Chinese market listing Corporation earnings ratio analysis of a cited the fluctuation of the overall situation, industry and the overall price earnings ratio were observed, and on the review of the related literature at home and abroad on the basis, the fluctuation analysis, may affect the price earnings ratio factor to carry on the summary. At the same time, China's price earnings ratio and the other major stock markets of the world for comparative analysis.
\end{abstract}

\section{Introduction}

Price-earnings ratio reflects the size of the investment value of listed companies and the degree of risk. The higher the price-earnings ratio, the company's investment is in lower price, share price to get a bigger crisis. Profit is the core of enterprises, corporate profitability is stronger, the company will create more profits for shareholders, in the case of shares the same price-earnings ratio will be lower, the company's investment value increase. If profitability is lower, the price- earnings rise, the company's investment value will decrease. If there is no change in profitability, share prices rise, indicating that investors will spend more money to buy the assets of equal value, the company's investment value will be low, price-earnings will rise; on the contrary, if the share price falls, the company's profitability did not change, then the investment value of the underlying stock will increases.

\section{Analysis of Financing of Listed Companies in China}

The total amount of fund raised is 1,063,018 million RMB from domestic and foreign financing of listed companies in China in 2014. The totals domestic funding is 841.24 billion Yuan, including issuing new shares funding for the first time is totals 66.889 billion Yuan, public financing for additional 1.826 billion Yuan, private placement financing is 403.13 billion Yuan, rights issue funding is 13.798 billion Yuan. Public approval of financing for additional is strict and for a long time, and there is issuance risks. In 2015 the total domestic and foreign financing of Chinese listed companies is 2,869,258million Yuan. The total domestic funding is 2,949,363million Yuan, the total funding of issuing new shares for the first time is 157.808 billion Yuan, 670.948 billion yuan private placement financing, offering financing 4.233 billion Yuan.

China listed company finance is shown in the following table

Analysis of the average market value of listed companies in China

From May 24, 2016 market data knowledge; we know that the listed companies total market value distribution is mainly distributed in more than 1.5 billion Yuan. Total market value of ICBC is 1518.29 billion Yuan; it is the biggest list company. Total market value and the smallest is *ST enterprise, the Total market value is 226.36billion Yuan. 
The most distribution of circulation market value of listed companies is more than 500 million Yuan. Oil, China is the largest in circulation; its market value is 1169.077. The company with the smallest market value is Red Sun energy, its market value is 11.148billion Yuan.

Table 1 the statistics for the funding from the security market in 2014-2015

\begin{tabular}{c|c|c|c|c|c|c|c}
\hline & \multirow{2}{*}{$\begin{array}{c}\text { Total } \\
\text { time }\end{array}$} & \multirow{2}{*}{\begin{tabular}{c} 
Domestic \\
funding(bill \\
ion yuan) \\
\cline { 5 - 8 }
\end{tabular}} & $\begin{array}{c}\text { funding(bill } \\
\text { ion yuan) }\end{array}$ & $\begin{array}{c}\text { A share } \\
\text { (billion } \\
\text { yuan) }\end{array}$ & $\begin{array}{c}\text { Public } \\
\text { fundin } \\
\text { g }\end{array}$ & $\begin{array}{c}\text { IPO } \\
\text { placement }\end{array}$ & \multicolumn{4}{|c}{ refunding } \\
funding & $\begin{array}{c}\text { A share(billion yuan) } \\
\text { se }\end{array}$ \\
\hline Total & 1063.018 & 842.701 & 66.889 & 1.826 & 403.130 & 13.798 & 0.00 \\
\hline $\begin{array}{c}\text { Total } \\
2014\end{array}$ & 2869.258 & 2949.363 & 157.808 & 0.00 & 670.948 & 4.233 & 0.00 \\
\hline
\end{tabular}

(source: monthly report Dec.2015 from the security market)

From the top 10 and the lowest 10 we can see that the ratio of the state-owned enterprises is still very large. But with the change of ownership structure, Private enterprises have been able to catch up with the size of the state-owned enterprises. They grow fast even in an increase of more than 1 time.

Market value is growing so fast that allows us to experience the process of quantitative change to qualitative change. We also can see that the small companies by market capitalization are less and less, while the increasing in company number with more than 40 billion Yuan, which explains our company structure, has been optimized. In addition, there is a rimming for the valuations on the stock market. In terms of size, the ratio of particularly large or particularly small companies is less; medium-scale enterprises is becoming the mainstay

Regionally, growth in the Western region is ranked on the national front, it is because they have strong sense of innovation, and development is in a good condition.

\section{Analysis of the Overall Price-Earnings of China's Shanghai and Shenzhen Stock Markets}

According to table 2, global economic data show that the price-earnings in Shenzhen second board stock trades is 67.18; the price-earnings in Shenzhen SME Board stock trading is 45.39, Shenzhen Board stock trading is 22.81 . The overall average price-earnings ratio of Shenzhen stock is 36.86 . Shanghai stock market average price-earnings ratio for 13.99 on May 16, 2016.Analysis of the fluctuation of China's Shanghai and Shenzhen stock market price/earnings ratio. In May 2016, the Shanghai a-share price-earnings ratio is 13.88; Shenzhen's A-share price-earnings ratio is 36.34; Hong Kong stock price-earnings ratio is 9.78 .

Since 2002, Shanghai stock market price/earnings ratio maintained between 20 to 40 times; the ratios peaked in the 2007 year. Since effects of the world financial crisis in 2008, China's stock market also fell; the ratio also fell sharply, but remained in 10-20 times.

On the other hand, price-earnings swing close to nearly 40 times in Shenzhen stock market, which in the 2005 and 2008 it fell in a large range, although in the last two years has rebounded, but volatility has repeatedly changed. 


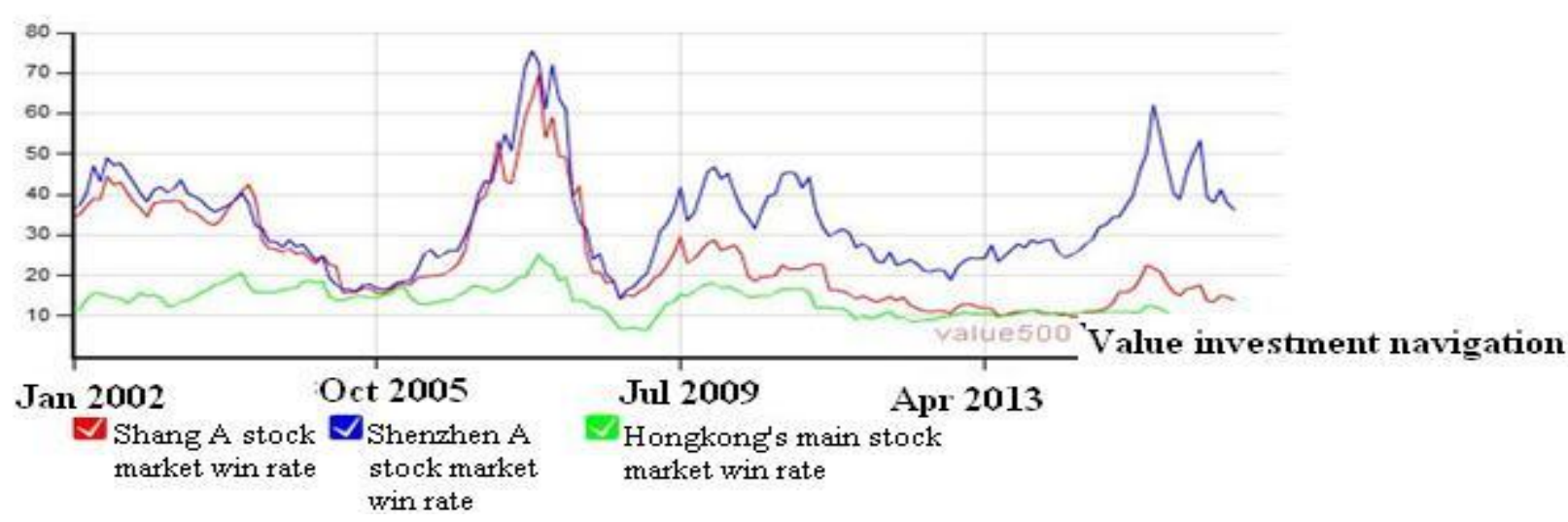

Figure 1. the trend of A-share average price/earnings ratio

Table 2 price-earnings ratio from Shenzhen and shanghai stock market

\begin{tabular}{|c|c|c|}
\hline date & $\begin{array}{c}\text { P/E ratio } \\
\text { A-share in Shanghai stock } \\
\text { market }\end{array}$ & $\begin{array}{c}\text { P/E ratio } \\
\text { A-share in Shenzhen stock market }\end{array}$ \\
\hline Feb. 2016 & 15.08 & 41.28 \\
\hline Jan. 2016 & 13.5 & 38.01 \\
\hline Dec. 2015 & 13.73 & 39.34 \\
\hline Nov. 2015 & 17.04 & 49.93 \\
\hline Oct. 2015 & 16.69 & 45.65 \\
\hline Sept. 2015 & 15.1 & 38.85 \\
\hline Aug. 2015 & 15.81 & 40.33 \\
\hline July. 2015 & 18.04 & 47.34 \\
\hline June 2015 & 20.92 & 54.92 \\
\hline May 2015 & 21.92 & 62.16 \\
\hline Apr. 2015 & 22.55 & 50.24 \\
\hline Mar. 2015 & 18.97 & 45.87 \\
\hline Feb. 2015 & 16.57 & 39.86 \\
\hline Jan. 2015 & 15.94 & 37.35 \\
\hline Dec. 2014 & 15.99 & 34.59 \\
\hline Nov. 2014 & 13.14 & 34.36 \\
\hline Oct. 2014 & 11.8 & 32.5 \\
\hline Sept. 2014 & 11.48 & 32 \\
\hline Aug. 2014 & 10.68 & 28.91 \\
\hline July 2014 & 10.58 & 27.68 \\
\hline June 2014 & 9.8 & 26.17 \\
\hline May 2014 & 9.76 & 25.17 \\
\hline Apr. 2014 & 10.65 & 24.47 \\
\hline Mar. 2014 & 10.66 & 25.62 \\
\hline Feb. 2014 & 10.73 & 28.87 \\
\hline Jan. 2014 & 10.57 & 28.72 \\
\hline
\end{tabular}

(SOURCES: Shanghai Stock Exchange)

Analysis of the fluctuation of China's Shanghai and Shenzhen stock market industry price-earnings

Price-earnings ratio is in line with the new share issuance system at the beginning of the reform, giving investors a reference; get them to buy new shares. It is helpful for pricing and trading 
reasonably. Today, the Shanghai stock market and Shenzhen stock market issue daily price-earnings ratios; they can help investors value the market valuations and help them consider more comprehensive and detailed at the time of investment.

In consideration of the structure, there was a little problem for the basic raw material industries in our industry right now. Generally speaking, we have defined a period of time; enterprises use its existing conditions and technologies, produce goods. But all these goods are more than we can consume, resulting in a slightly depressed in these industries. Other industries who have only a few sellers, standing on high ground in control of everything, cannot lead us to consume and provide.

We have the China Securities index company data as sample.

From the table, nearly one year the top ten industries increase in amount per are construction, general, real estate, transport, storage and postal services, leasing and business services, information transmission, software and information technology services, accommodation and catering industry, mining industry, manufacturing industry, wholesale and retail. They are $120.51 \%, 99.23 \%, 90.49 \%$, $85.17 \%, 79.82 \%, 78.92 \%, 72.52 \%, 68.36 \%$, and $62.74 \%$ respectively.

Table 3 China Shanghai and Shenzhen stock markets full market industry earnings

\begin{tabular}{|c|c|c|c|c|}
\hline $\begin{array}{l}\text { Industry } \\
\text { code }\end{array}$ & Name & $\begin{array}{l}\text { Average } P / E \\
\text { ratio } 2014\end{array}$ & $\begin{array}{l}\text { Average } \mathrm{P} / \mathrm{E} \\
\text { ratio } 2015\end{array}$ & increase \\
\hline A & $\begin{array}{l}\text { agriculture, forestry, husbandry } \\
\text { and fishery; }\end{array}$ & 65.02 & 97.11 & $49.35 \%$ \\
\hline $\mathrm{B}$ & mining & 11.44 & 19.26 & $68.36 \%$ \\
\hline $\mathrm{C}$ & manufacturing & 28.37 & 46.17 & $62.74 \%$ \\
\hline $\mathrm{D}$ & $\begin{array}{l}\text { Electricity, heat, gas and water } \\
\text { production and supply industry }\end{array}$ & 14.41 & 23.09 & $60.24 \%$ \\
\hline $\mathrm{E}$ & Construction business & 10.14 & 22.36 & $120.51 \%$ \\
\hline $\mathrm{F}$ & Wholesale and retail trade & 26.27 & 44.55 & $69.59 \%$ \\
\hline $\bar{G}$ & $\begin{array}{l}\text { Transportation, warehousing and } \\
\text { postal services }\end{array}$ & 15.85 & 29.35 & $85.17 \%$ \\
\hline $\mathrm{H}$ & $\begin{array}{l}\text { Accommodation and catering } \\
\text { industry }\end{array}$ & 49.2 & 84.88 & $72.52 \%$ \\
\hline $\mathrm{I}$ & $\begin{array}{l}\text { Information } \begin{array}{r}\text { transmission, } \\
\text { software and information } \\
\text { technology services }\end{array} \\
\end{array}$ & 58.15 & 104.04 & $78.92 \%$ \\
\hline $\mathrm{J}$ & Finance & 6.79 & 10.48 & $54.34 \%$ \\
\hline $\mathrm{K}$ & Real Estate & 12.83 & 24.44 & $90.49 \%$ \\
\hline $\mathrm{L}$ & Leasing and business services & 34.14 & 61.39 & $79.82 \%$ \\
\hline $\mathrm{M}$ & $\begin{array}{l}\text { Scientific research and technical } \\
\text { services }\end{array}$ & 49.15 & 67.15 & $36.62 \%$ \\
\hline $\mathrm{N}$ & $\begin{array}{l}\text { Water resources, environment } \\
\text { and public facilities management }\end{array}$ & 27.03 & 40.12 & $48.43 \%$ \\
\hline $\mathrm{O}$ & $\begin{array}{l}\text { Residents service, repair and } \\
\text { other services }\end{array}$ & & & \\
\hline $\mathrm{P}$ & education & & & \\
\hline $\mathrm{Q}$ & Health and social work & & 131.65 & \\
\hline $\mathrm{R}$ & $\begin{array}{lll}\begin{array}{l}\text { Culture, } \\
\text { entertainment }\end{array} & \text { sports } & \text { and } \\
\end{array}$ & 42.43 & 62.91 & $48.27 \%$ \\
\hline$S$ & comprehensive & 33.97 & 67.68 & $99.23 \%$ \\
\hline
\end{tabular}

(sources: China Securities Index Co., Ltd) 


\section{Conclusions}

China listed company's price-earnings ratio is higher than the world average of index average while normal, but part of the overall was slightly higher. Financial, real estate, price-earnings ratio is not high at this point, can be considered part reduces the average price/earnings ratio.

Due to the growth of the Chinese economy, special national basic conditions, capital markets, and formula for calculating the price/earnings ratio there are a few flaws and the data source not exactly sure we can't as the sole basis for earnings, but should be considered a general measure.

Other side, the earnings difference is relatively large, contacts within the a-share stock price-earnings ratio also has a lot of different price-earnings ratio is closely related to other factors, only when we cannot invest its height. But careful study of current macro-economic policies at home and abroad, and a combination of various indicators of stock investment value, multiples of sound judgment, and to correctly grasp the understanding and application of earnings in order to avoid blind investment and inappropriate behavior.

\section{References}

[1] Penman S. The articulation of price-earnings ratios and market-to-book ratios and the evaluation of growth [J] . Journal of Accounting Research, 1996, 34(2): 235-259

[2] Sinha S. High Price-Earnings Ratio of Indian Stock Market and Investment by Foreign Financial Institutions[J].Economic and Political Weekly,1994,22(1):96-100

[3] La porta, Rafael and Robert Vishny. Good News for Value Stocks: Futher Evidence On Market Efficiency[J].Journal of Finance, 1997,52(2):859-947

[4] Xia Jing. China's securities brokerage business research [J]. Journal of economic study Tribune, 2011, 24 (1): $78-83$

[5] The China securities regulatory commission. China's capital market twenty years [M]. (version 1). Beijing: China citic publishing house, 2012.524 - 525

[6] Yuan Changzheng, Li Zhi. The development course of China's securities industry regulation change study [J]. Journal of front, 2011 (1): 104 - 107

[7] John Gordon. Great game: the rise of Wall Street financial empire [M]. QiBinYi. Version 1. Beijing: China citic press, 2012.23 - 525

[8] Lei Bing. 24 key financial indicators of stock investment [M]. (Version 1). Beijing: China aerospace press, 2012.107 - 118

[9] Xiao DaYong. Classification based on the size of the listed company P/E ratio difference research [D]. Master degree theses of master of the Shanghai academy of social sciences. 2013.17-26

[10] Tian Ye. Also the listed securities and bank of China p/e ratio difference cause analysis [D]. Master degree theses of master of Fudan University. 2014.39-40 